\title{
The Assessment of Polysaccharides, Mucosubstances and Colagen IV in Kindler Syndrome
}

\author{
DALIA DOP ${ }^{1}$, ILEANA PUIU ${ }^{1 *}$, CRISTINA ELENA SINGER ${ }^{1}$, SIMONA IANOSI $^{2}$, \\ CATALIN PLESEA CONDRATOVICI ${ }^{3}$, SORIN BERBECE ${ }^{3}$, CARMEN ELENA NICULESCU ${ }^{1}$ \\ ${ }^{1}$ University of Medicine and Pharmacy of Craiova, Pediatrics Department, 2 Petru Rares Str., 200349 Craiova, Romania \\ ${ }^{2}$ University of Medicine and Pharmacy of Craiova, Dermatology Department, 2 Petru Rares Str., 200349 Craiova, \\ Romania \\ ${ }^{3}$ Dunarea de Jos, University, Faculty of Medicine and Pharmacy, Department of Morphological and Functional Sciences, \\ 47 Domneasca Str., 800008, Galati, Romania
}

\begin{abstract}
Kindler syndrome is a rare autosomal recessive genodermatosis characterized by particular fragility of the skin and mucosa, manifesting in the appearance of bullae in minor traumas, photosensitivity, diffuse cutaneous atrophy and progressive poikiloderma. It is caused by mutations in the FERMT1 gene encoding kindlin-1. We present the case of a 12-year-old girl diagnosed with Kindler syndrome showing the classical clinical features affecting the skin, in addition to nail involvement, gingivitis, periodontitis, growth retardation, mental retardation, esophageal and anal stenosis. The histopathological examination of a cutaneous biopsy revealed the presence specific features of Kindler syndrome.
\end{abstract}

Keywords: Kindler syndrome, photosensitivity, esophageal and anal stenosis, skin biopsy

Epidermolysis bullosa was first described in 1886 and it represents a group of diseases characterized by various degrees of cutaneous involvement determined by mutations in various structural proteins of the skin [1]. In 2007, at the Third International Consensus Meeting on Diagnosis and Classification of Epidermolysis Bullosa held in Vienna, Austria, Kindler syndrome was included in the Epidermolysis bullosa group, together with the simplex, junctional and dystrophic forms [2].

Kindler syndrome (KS) is a rare genodermatosis characterized by particular fragility of the skin and mucosa, manifesting in the appearance of bullae in minor traumas in infancy and childhood, photosensitivity, diffuse cutaneous atrophy and progressive poikiloderma. [3]. It is a polymorphous disease; alongside the skin involvement, we can also find mucosal involvement, syndactyly, mental retardation, involvement of the eyes, teeth or bones. [3,4,5]. It is a very rare disease, with approximately 250 cases reported in the world [6]. The transmission is predominantly recessive, but some cases of dominant transmission have also been reported [7].

In this article we present a case of Kindler syndrome in a 12-year-old girl, with a unique association of manifestations and poor prognosis secondary to mucosal involvement.

\section{Experimental part}

We present the case of a 12-year-old girl born of a non-consanguineous marriage. The onset of the symptoms occurred a few days after birth, with recurrent blistering on the hands and feet and ulcerations of minor traumas, which subsequently ruptured and often became secondarily infected and healed slowly; after healing, the patient presented white atrophic skin.

Subsequently, the patient presented progressive photosensitivity, alterations of the skin in the extremities, face, neck, and torso, poikiloderma, scars with cigarette paper wrinkling and diffuse palmoplantar hyperkeratosis. The family history was negative. She has a younger sister with no complaints.

During the physical examination, the patient presents ulcerative lesions on the calves and in the dorsolumbar region, xeroderma and diffuse cutaneous atrophy. The skin is fragile, with telangiectases; hypo- and hyperpigmentation on the trunk, especially in the upper part, as well as in the dorsolumbar region and on the limbs (Figure 1). She presents scars with cigarette paper wrinkling on the back of the hand and feet, diffuse palmoplantar hyperkeratosis and pseudoainhum (Figure 2). There were also periodontal diseases, xerostomia, gingivitis, premature loss of teeth (Figure 3), restricted mouth opening and angular cheilitis, nail dystrophy (onycholysis). transverse and longitudinal ridges, yellow discoloration).

The patient also presented growth retardation, mental retardation and chronic constipation. An anal stenosis was highlighted during the barium enema examination. The patient also complained of dysphagia, with the endoscopic examination revealing esophageal stenosis. The eye examination was within normal limits. Routine blood tests were within the normal range. 


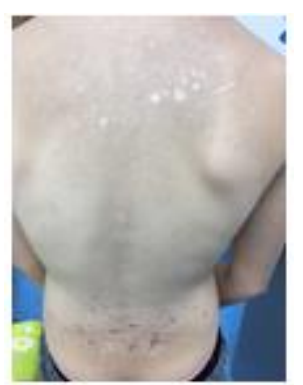

Fig. 1. Hypo- and hyperpigmentation on the trunk, especially in the upper part, as well as in the dorsolumbar region

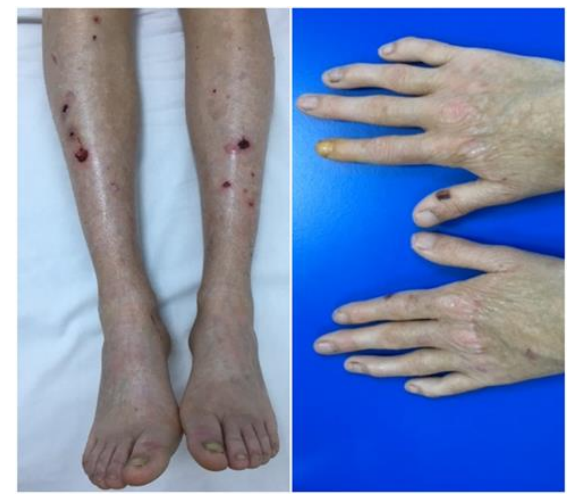

Fig. 2. Scars with cigarette paper wrinkling on the back of the hand and feet, diffuse palmoplantar hyperkeratosis and pseudoainhum

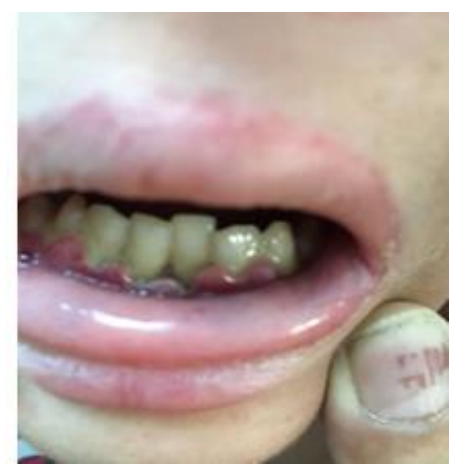

Fig. 3. Poor preservation of teeth and severe periodontitis

The histopathological examination of a cutaneous biopsy is performed.

The biopsy sample was fixated at ambient temperature in $10 \%$ calcium carbonate-buffered formalin. The initial histopathological processing, up until the paraffin block, was done automatically with the Bio-Optica closed loop system tissue processor. The samples embedded in paraffin were sectioned at 3-4 $\mu \mathrm{m}$ and stained with HemalaunEosin using the standard method (Bio-Optica kit). Subsequently, PAS coloration and immunological marking for collagen IV were performed on seriated sections. For the latter, we used the immunohistochemical study method in order to identify the epitopes of interest (Collagen IV), and the method was a two-cycle, polymer one, characterized by high sensitivity and elevated specificity and affinity. The anti-collagen IV antibody used, a CIV22 clone produced by DAKO, was diluted to 1:25 and it initially required antigenic site retrieval using a citrate buffer with pH 6.8 , for 7 cycles in the microwave oven.

Seriated sections with a thickness of 3 microns were executed from the paraffin blocks and were introduced in the Leica BOND-MAX autostainer, and the processing was done automatically, in accordance to the producer's specifications. The sections were incubated with primary antibody for an hour and for the detection of the primary antibody we used the Bond Polymer Refine Detection System; the immune reaction was viewed using DAB. Counterstaining was made with Mayer's Hematoxylin solution. 


\section{Results and discussions}

The microscopic examination of the Hematoxylin-Eosin stained sections revealed, in the skin biopsy samples, moderate hyperkeratosis, the presence of a subepidermal bulla with relatively maintained integrity of the cells in the basal layer of the epidermis. Adjacently, the examination identified extended areas of dermal-epidermal clefts, as well as moderate polymorphic inflammatory infiltrate in the superficial and middle dermis capillaries with discrete stasis, and collagen sclerosis.

The PAS stain (magenta) and the collagen IV immunolabeling (brown) have ascertained that the basal membrane remains attached to the underlying dermis, being situated on the "floor" of the bulla. Thus, the cleavage is present at the dermoepidermal junction, while the MB is maintained in the dermis (Figure 4-6).

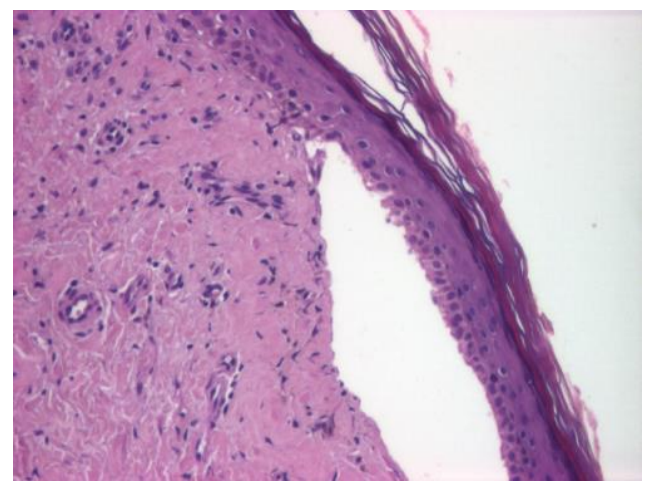

Fig. 4. Skin biopsy samples: moderate hyperkeratosis, the presence of a subepidermal bulla with relatively maintained integrity of the cells in the basal layer of the epidermis, Hematoxylin-Eosin staining, x 100

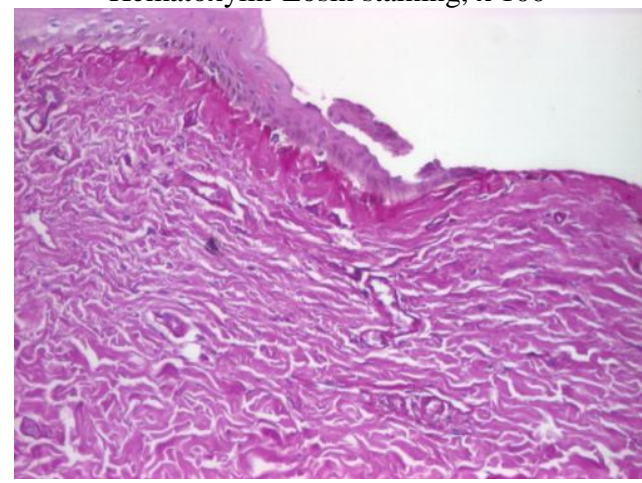

Fig. 5. Skin biopsy samples: periodic acid-Schiff (PAS) staining to detect polysaccharides and mucosubstances, $\mathrm{x} 100$

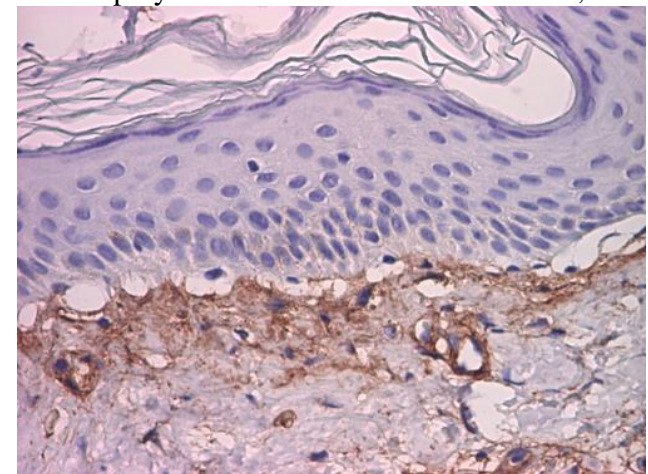

Fig. 6. Skin biopsy samples: colagen IV staining, x 200

The diagnosis of KS was made on the basis of clinical and histopathological examination. Molecular genetic testing is impossible for now, due to financial constraints.

A course of symptomatic treatment was instituted, and the patient was advised to avoid exposure to sunlight; she was also referred to a specialized center for esophageal dilations and the necessary surgery for the severe anal stenosis and the secondary megacolon she had developed.

Kindler syndrome was first described from a clinical point of view in 1954 by Theresa Kindler, and in 2003 the genetic cause was identified in the mutations of the KIND1 gene in the 20p12.3.2 chromosome [8].This gene codifies a focal adhesion protein - kindlin 1, which activates the receptors of the integrin family in the extracellular matrix [9]. In most case of KS, there is a marked decrease or a complete absence of the kindlin-1 protein in the keratinocytes, with subsequent adhesion, migration and faulty cell proliferation, as well as epithelial insensitivity to electric fields[10]. The proliferation defect, together with the loss of basal keratinocytes through apoptosis, explains the profound atrophy of the skin [9]. The type VII collagen in KS is found in abnormal locations deep in the connective 
tissue stroma and type IV collagen were present in blister areas appeared on the floor suggesting cleavage at the level of the lamina lucida $[11,12]$

Characteristic for KS is the onset during the first months of life, with the emergence of acral blisters; later on, the infant presents photosensitivity that is generally diminished with age. Subsequently, the child presents skin atrophy, poikiloderma and gingivitis. Some children also present eye involvement, nail dystrophies, syndactyly, joint hypermobility, bifid or missing ribs, palmoplantar keratoderma, leukokeratosis of the oral mucosa, pseudoainhum, mental retardation and growth retardation [3-5,7,13-15]. The unfavorable prognosis is determined by the presence of esophageal, urethral, and anal stenosis and the high risk of developing squamous cell carcinomas after the fourth or fifth decade of life [7, 16-19].

The diagnosis for KS is clinical, but it is sustained by the histopathological exam which is non specific, electronic microscopy, immunostaining with anti-kindlin-1 antibody and genetic testing [6,20,21,22]

The most characteristic histological abnormality found in the skin of Kindler syndrome is vacuolar degeneration of the basal layer of the epithelium, epidermal atrophy, pigmentary incontinence and mild lymphocytic infiltrate in the upper dermis, consistent with poikiloderma [14,15,23,24]. Electron microscopy shows major disorganization of the basement membrane, with duplication and disruption of the lamina densa, and formation of clefts observed in the lamina lucida $[9,25]$.

The characteristics of the syndrome have been highlighted by many authors, but it wasn't until 2005 that Angelova Fisher and collaborators proposed diagnostic criteria. Thus: a) the major criteria include: acral blisters in infancy and childhood, progressive poikiloderma, diffuse skin atrophy, abnormal photosensitivity, gingival fragility and/or swelling; b) the minor criteria include: syndactyly and mucosal involvement (anal, esophageal, urethral, laryngeal stenosis); c) associated findings are: nail dystrophy, ectropion, pseudoainhum, leukokeratosis of the lips, anhidrosis/hypohidrosis, palmoplantar keratoderma, squamous cell carcinomas, skeletal abnormalities, periodontitis/poor dentition. According to the criteria put forward, the presence of 4 major criteria makes the diagnosis of KS certain; the presence of 3 major and 2 minor criteria makes the diagnosis probable, and the presence of 2 major criteria and 2 minor criteria or associated symptoms makes the diagnosis likely [3]. These diagnostic criteria have not been reviewed until now, although there were authors who claimed they should be [17].

Our patient had all 5 major criteria, as well as nail involvement, pseudoainhum, gingivitis, periodontitis, growth retardation, mental retardation, esophageal and anal stenosis. We did not find this clinical association reported in any case of KS.

The differential diagnosis of Kindler syndrome includes other rare disorders such as epidermolysis bullosa ,Weary syndrome, Bloom syndrome, Cockayne syndrome, dyskeratosis congenita, Rothmund-Thomson syndrome and xeroderma pigmentosum [18].

In newborns it might be difficult to differentiate KS from epidermolysis bullosa, but the presence of photosensitivity, the improvement of blistering with age, poikilodermatous changes and the appearance of skin atrophy help to differentiate [13].

Weary syndrome has been mistaken for KS because of the similar symptoms, but photosensitivity is usually absent in patients with Weary syndrome, skin atrophy is reduced and acral blisters appear within the first 6 months of life. Also, in Weary syndrome there are keratotic papules that develop on the back of the hands, elbows, and knees, while there is no mucosal involvement [14,25-27].

Bloom's syndrome is characterized by photosensitivity, telangiectasia and the presence of erythema on the areas exposed to sunlight, without showing poikiloderma. There is also the presence of recurrent infections and the increased frequency of hematological malignancies [14,28,29].

Erythema in photo-distributed areas, atrophy, and hyperpigmentation, progressive pigmentary retinopathy, dwarfism, cachexia, deafness, and birdlike faces are characteristic features of Cockayne's syndrome [13,14].

Rothmund-Thomson syndrome shows generalized poikiloderma, photosensitivity, nail dystrophy, hyperkeratosis of the palms, hands and wrists, in addition to alopecia, hypogonadism, microcephaly, and cataract that are not seen in Kindler syndrome [3,14,19,30-32].

Photosensitivity and poikilodermatous changes in photo-exposed skin are present in xeroderma pigmentosum, but without the skin fragility found in patients with Kindler syndrome. Additionally, they have multiple neurological abnormalities and develop early-onset skin cancers [14,33,34]. Dyskeratosis congenita is characterized by reticulated hyperpigmentation, nail dystrophy, leukoplakia, while the pigmentary changes are not really poikilodermatous [14,3537].

Management of KS is preventive and symptomatic. Patients should be advised to avoid sunlight and traumas and use topical or/and systemic antibiotic treatment for the infected bullous lesions. Patients have a normal life span, but morbidity may be caused by secondary infections of congenital blisters, urethral, anal and esophageal stenosis, ocular complications, periodontitis and skin malignancies. 


\section{Conclusions}

It is important to know the multiple manifestations of Kindler syndrome in order to establish an early diagnosis and to ensure an adequate management, which requires education on photoprotection and permanent monitoring of orodental complications, skin and mucosa malignancies and esophageal, anal and urethral stenoses.

\section{References}

1.LIZBETH, R.A., INTONG, DÉDÉE, F., MURRELL, Inherited epidermolysis bullosa: New diagnostic criteria and classification, 30, 1, 2012, p. $70-77$.

2.FINE, J.D., EADY, R.A., BAUER, E.A., BAUER, J.W., BRUCKNER-TUDERMAN, L., HEAGERTY, A., HINTNER, H., HOVNANIAN, A., JONKMAN, M.F., LEIGH, I., MCGRATH, J.A., MELLERIO, J.E,, MURRELL, D.F., SHIMIZU, H., UITTO, J., VAHLQUIST, A., WOODLEY, D., ZAMBRUNO, G., The classification of inherited epidermolysis bullosa (EB): Report of the Third International Consensus Meeting on Diagnosis and Classification of EB, J Am Acad Dermatol, 58, 6, 2008, p. 931-950.

3.FISCHER, I.A., KAZANDJIEVA, J., VASSILEVA, S., DOURMISHEV, A. Kindler syndrome: A case report and proposal for clinical diagnostic criteria. Acta Dermatovenerol Alp Pannonica Adriat, 14, 2005, p. 61-67.

4.BARBOSA, N.M., VISIOLI, F., MARTINS, M.D., MARTINS, M.A., MUNERATO, M.C., Oral manifestations in Kindler syndrome: case report and discussion of literature findings, Spec Care Dentist, 36, 4, 2016, p. 223-230.

5.PENAGOS, H., JAEN, M., SANCHO, M.T., SABORIO, M.R., FALLAS, V.G., SIEGEL, D.H., FRIEDEN, I.J., Kindler syndrome in native Americans from Panama: Report of 26 cases, Arch Dermatol, 140, 2004, p. 939-944.

6.DOBREV, H.P. VUTOVA, N.I., Nailfold capillaroscopic changes in Kindler syndrome, Intractable Rare Dis Res, 4, 4, 2015 , p.214-216.

7.MAHESHWARI, A., DHAKED, D.R., MATHUR, D.K., BHARGAVA, P,. Kindler syndrome with palmoplantar hyperhidrosis and blonde hair, Indian Dermatol Online J, 6, 5, 2015, p. 330-332.

8.SIEGEL, D.H., ASHTON, G.H., PENAGOS, H.G., LEE, J.V., FEILER, H.S., WILHELMSEN, K.C., SOUTH, A.P., SMITH, F.J., PRESCOTT, A.R., WESSAGOWIT, V., OYAMA, N., AKIYAMA, M., AL ABOUD, D., AL ABOUD, K., AL GITHAMI, A., AL HAWSAWI, K., AL ISMAILY, A., AL-SUWAID, R., ATHERTON, D.J., CAPUTO, R., FINE, J.D., FRIEDEN, I.J., FUCHS, E., HABER, R.M., HARADA, T., KITAJIMA, Y., MALLORY, S.B., OGAWA, H., SAHIN, S., SHIMIZU, H., SUGA, Y., TADINI, G., TSUCHIYA, K., WIEBE, C.B., WOJNAROWSKA, F., ZAGHLOUL, A.B., HAMADA, T., MALLIPEDDI, R., EADY, R.A., MCLEAN, W.H., MCGRATH, J.A., EPSTEIN, E.H. . Loss of kindlin-1, a human homolog of the Caenorrhabditis elegans actin-extracellularmatrix linker protein UNC-112, causes Kindler syndrome, Am J Human Genet, 73, 2003, p. 174-187.

9.HERZ, C., AUMAILLEY, M., SCHULTE, C., SCHLÖTZER-SCHREHARDT, U., BRUCKNER-TUDERMAN, L., HAS. C., Kindlin-1 is a phosphoprotein involved in regulation of polarity, proliferation, and motility of epidermal keratinocytes, J Biol Chem, 281, 47, 2006, p.:3608236090.

10.ZHANG, G., GU, Y., BEGUM, R., CHEN, H., GAO, X., MCGRATH, J.A., PARSONS, M., SONG, B., Kindlin-1 Regulates Keratinocyte Electrotaxis, J Invest Dermatol, 136, 11, 2016, p.2229-2239.

11.WIEBE, C.B., LARJAVA, H.S., Abnormal deposition of type VII collagen in Kindler syndrome, Arch Dermatol Res, 291, 1999, p. 6-13.

12.LARJAVA, H., PLOW, E.F., WU, C., Kindlins: essential regulators of integrin signalling and cell-matrix adhesion, EMBO reports, 9, 12, 2008, p. 1203-1208.

13.SUMAN, N., KAUR, S., KAUR, S., SARANGAL, V., Kindler's syndrome: A rare case report, Contemp Clin Dent, 5, 2, 2014 , p. $217-220$. 14.GHOSH, S.K., BANDYOPADHYAY, D., DAS, J., CHATTERJEE, G., SARKAR, S., Kindler'S syndrome: a case series of three Indian children. Indian J Dermatol, 55, 4, 2010, p. 393-396.

15.MENDES, L., NOGUEIRA, L., VILASBOAS, V., TALHARI, C., TALHARI, S., SANTOS, M., Kindler syndrome: report of two cases, An Bras Dermatol, 87, 5, 2012, p. 779-781.

16.SHIMIZU, H., SATO, M., BAN, M., KITAJIMA, Y., ISHIZAKI, S., HARADA, T., BRUCKNER-TUDERMAN L, FINE JD, BURGESON R, KON A, MCGRATH JA, CHRISTIANO, A.M., UITTO, J., NISHIKAWA, T., Immunohistochemical, ultrastructural, and molecular features of Kindler syndrome distinguish it from dystrophic epidermolysis bullosa, Arch Dermatol, 133, 9, 1997, p. 1111-1117.

17.AL ABOUD, K., AL HAWSAWI, K.. Kindler syndrome with facial telangiectatic hyperpigmentation: need for modification of diagnostic criteria, Acta Dermatovenerol Alp Pannonica Adriat, 16, 1, 2007, p. 42-43.

18.ANWAR, M.I., RASHID, A., GHAFOOR, R., TAHIR, M., RAO, S.U., MIR, F., Kindler's syndrome: a report of five cases in a family, 24, 10, 2014, p. 763-765.

19.WANG, L.L., LEVY, M.L., LEWIS, R.A., CHINTAGUMPALA M.M., LEV, D., ROGERS, M., PLON, S.E., Clinical manifestations in a cohort of 41 Rothmund-Thomson syndrome patients, Am J Med Genet, 102, 1, 2001, p. 11-17.

20.WAYLI, H.A., Xeroderma pigmentosum and its dental implications, Eur J Dent, 9, 1, 2015, p. 145-148.

21.PETRESCU, I.O., PLEŞEA, I.E., FOARFĂ, M.C., BONDARI, S., SINGER, C.E., DUMITRESCU, E.M., PANĂ, R.C., STĂNESCU, G.L., CIOBANU, M.O. Rare thymic malignancy of B-cell origin - T-cell $\div$ histiocyte-rich large B-cell lymphoma. Rom J Morphol Embryol, 57, 3 , 2016, p.1075-1083.

22.MARINĂU, L.D., SINGER, C.E., MEŞINĂ, C., NICULESCU, E.C., PUIU, I., PETRESCU, I.O., GEORMĂNEANU, C., ENCULESCU, A.C., TACHE, D.E., PURCARU, Ş.O., RĂCIULĂ, S., DAMIAN, C.L. Two girl patients with medulloblastoma. Case reports. Rom J Morphol Embryol, 58, 3, 2017, p. 1103-1108.

23.GURAU, G., DINU, A.C., EARAR, K., VOICU, D.C, BOTEZATU, D. Rev. Chim. (Bucharest), 67, no. 3, 2016

24.DINU, A.C., BRUJBU, I., CERGHIZAN, D., BULIMAR, V., MACOVEI, L.A., BOTEZATU, D. Rev. Chim. (Bucharest), 67, no. 6, 2016

25.POPESCU, M., POPESCU, I.A., STANCIU, M., CAZACU, S.M., IANOŞI, N.G., COMĂNESCU, M.V., SINGER, C.E., NEAGOE, C.D. Non-alcoholic fatty liver disease - clinical and histopathological aspects. Rom J Morphol Embryol, 57, 4, 2016, p. 1295-1302.

26.TITIUCA, C., DINU, A.C., ALEXA, I.A., PRUNA, R., LUCA, M.C., DOROBAT, C., VATA, A., LUPOAE, M. Rev. Chim. (Bucharest), 67, no. 5,2016

27.MACOVEI, L.A., CRISTESCU, V., DEBITA, M., DINU, A.C. Rev. Chim. (Bucharest), 68, no. 10, 2017

28.SINGER, C.E., COŞOVEANU, C.S., CIOBANU, M.O., STOICA, G.A., PUIU, I., GRUIA, C.L., STREBA, L., CONSTANTIN, C., NEAGOE, C.D. Hirschprung's disease in different settings - a series of three cases from a tertiary referral center. Rom J Morphol Embryol, 56, 3, 2015 p. 1195-200.

29.NECHITA, D., NECHITA, F., MOTORGA, R., A review of the influence the anxiety exerts on human life, Rom J Morphol Embryol, 59, 4, 2018, p. 1045-1051.

30.NECHITA, F., NECHITA, D., PIRLOG, M.C., ROGOVEANU, I., Stress in medical students, Rom J Morphol Embryol, 5, 3, 2014, p. 12631266.

31.NECHITA, F., PIRLOG, M.C., CHIRITA, A.L., Circadian malfunctions in depression - neurobiological and psychosocial approaches, Rom J Morphol Embryol, 56, 3, 2015, p. 949-955. 
32.LupU, V.V., IGNAT, A., PADURARU, G., CIUBARA, A., IONIUC, I., CIUBARA, A.B., GHEONEA, C., BURLEA, M., The Study of Effects Regarding Ingestion of Corrosive Substances in Children, Rev. Chim. (Bucharest) 67, no. 12, 2016, p. 2501-2503.

33.ANOAICA, P.G., AMZOIU, E., BOZZINI, F., AVERIS, L.M.E., BUBULICA, M.V., GHEONEA, C.A., Predictive and Invariant "in silico" Model for the Transmembrane Partition Coefficient in a Wide Series of Benzene Derivatives., Rev. Chim. (Bucharest), 66, no. 3, 2015, p. 390395.

34.CRINGUS, L.I., PETRESCU, F., CALBOREAN, V., ROTARU, L.T., MARGINEAN, C., MESINA C, BUNESCU, M.G., DINESCU, V.C., GHEORMAN, V., DIJMARESCU, A.L., UDRISTOIU, I., CIOBANU, D., The Host Response to Chronic Hepatitis B Infection, Rev. Chim. (Bucharest), 70, no. 2, 2019, p. 646-650.

35.RAFTU, G., DEBITA, M., DINU, A.C., PANGAL, A.,HODOROG, D., CUCIUREANU, D.I. Rev. Chim. (Bucharest), 70, no. 1, 2019, p. 228

36.CALBOREAN V, UDRISTOIU I, DOCEA AD, HODOROG MC, DINESCU SN, CRICIOTOIU O, STANCA D , MITA A, DAVITOIU DV , BALEANU VD , ROMANESCU FM , BICA M ,MIREA CS , DINESCU VC. Evaluation of Echocardigraphic Parameters in Patients with Rhythm Disorders Associated with Chronic Hepatic Diseases, Rev. Chim. (Bucharest), 70, no. 2, 2019, p. 659-663.

37.PAVEL, L.L., TITIUCA, C., BERBECE, S., PLESEA, A.P. Rev. Chim. (Bucharest), 68, no. 5, 2017, p. 1095-1097

Manuscript received: 10.07 .2019 